\title{
Obesity Health Policy Agenda Setting in Australia
}

\author{
Hilal Salim Al Shamsi ${ }^{1} \&$ Abdullah Ghthaith Almutairi ${ }^{2}$ \\ ${ }^{1}$ Director of Planning and Studies, Directorate General of Planning and Studies, Ministry of Health, Al Buraimi, \\ Oman \\ ${ }^{2}$ Director of Tumair Hospital, Ministry of Health, Riyadh, Saudi Arabia \\ Correspondence: Hilal Salim Al Shamsi, Director of Planning and Studies, Directorate General of Planning and \\ Studies, Ministry of Health, Al Buraimi, Oman.
}

Received: October 23, 2020 Accepted: February 9, 2021 Online Published: February 15, 2021

doi:10.5539/gjhs.v13n3p138 URL: https://doi.org/10.5539/gjhs.v13n3p138

\begin{abstract}
The prevalence of obesity is rising rapidly in Australia. This issue can be a priority for agenda setting, by using the Hall and Kingdon models. Furthermore, the current policy may need to be reviewed or updated because of the high prevalence of obesity and the rate of death.
\end{abstract}

Keywords: obesity, health policy Australia, aganda setting

\section{Introduction}

Obesity is a serious issue facing Australia and other developed countries. Health policy can provide a framework for establishing prevention and intervention activities aimed at treating obesity. The first step of the policy cycle is agenda setting, and it focuses the attention of policy makers on obesity related issues. This essay will use the Hall and Kingdon models to discuss the priority of the obesity issue over other issues when it comes to agenda setting. The paper will also address the role of different groups, including the government, in agenda setting.

\section{Obesity in Australia}

Obesity is a serious health issue both in Australia and throughout the world. Obesity is calculated by using the body mass index (BMI), which divides the human body weight in kilograms by the square of the body height in metres (Australian Institute of Health and Welfare [AIHW], 2016a). According to the AIHW, BMI $<18.5$ is considered underweight, $18.5 \leq \mathrm{BMI}<25$ is normal weight, $25 \leq \mathrm{BMI}<30$ is overweight, and $\mathrm{BMI} \geq 30$ is obese. The prevalence of obesity in 1999-2000 was two and a half times higher than in 1980 (Thorburn, 2005). Moreover, 67\% of Australian adults were either overweight or obese in 2015-2016 (AIHW, 2016b). The study also showed that $25 \%$ of Australian children were either overweight or obese during the same period. While the death rate for deaths directly attributed to obesity was 0.9 per 100,000 people in 2009 , it was just 0.6 in 2000 (ABS, 2011). In brief, obesity is a significant problem in Australia, and a solution is needed.

\section{Agenda Setting}

Agenda setting is the first and perhaps the most important step of the policy cycle (Shah, McLeod, Gotlieb, \& Lee, 2009). Dearing and Rogers (1996) stated that policy makers could be professionals, media, policy elites, and the public. They pointed out that a proper scale to measure a person's weight should be used to understand and define this issue. The same paper also showed that agenda setting is not a guarantee that government action will resolve an issue; merely that government consideration has discriminated between it and other issues at any given time. The government does not have enough resources to deal with all society's issues at once. Therefore, to direct the attention of the government towards the issue of obesity and away from many other issues, it is necessary to identify the issue succinctly when setting an agenda.

\section{Why Obesity Came onto the Agenda}

The Hall and Kingdon models are two theoretical models that can be used to ensure obesity is addressed in agenda setting.

\subsection{Hall Model}

The Hall model argues that policy issues only get put on a policy agenda if the issue and possible solution have high legitimacy, feasibility, and public and government support in relation to the policy issue (Béland, 2005). 


\subsubsection{Legitimacy}

This stage of the model relates to the degree of seriousness of obesity in Australia. Specifically, as obesity increases, the attention of the government will also increase. It is therefore important to consider that only when the government is concerned about the seriousness of the obesity issue will it exercise its right to intervene. Obesity has three negative impacts on Australian society: it is costly, it has a high prevalence, and it is a health issue.

First, Colagiuri et al. (2010) stated that due to obesity and the health problems related to it, there are economic burdens on communities, families, and individuals in Australia. These authors showed that the direct cost of overweight and obesity was $\$ 21$ billion in 2005 . The direct cost of obesity alone was approximately $\$ 14.5$ billion. The same paper highlighted the estimated indirect costs of obesity as being approximately $\$ 35.6$ billion per year. The total overall cost related to overweight and obesity combined was $\$ 56.6$ billion during that period. In addition, Leung, Funder, and Clark (2014) stated that obesity has a cost impact on productivity, health systems, carers, and other fields.

Second, for the last 30 years, the prevalence of overweight and obesity has been increasing (National Health and Medical Research Council, 2016). Overweight and obesity are prevalent in approximately $60 \%$ of Australian adults, while only $25 \%$ of that group was obese in 2011 and 2012, according to the National Health and Medical Research Council (2016).

Third, obesity is the main risk factor for many diseases, such as obstructive sleep apnoea, cardiovascular disease, renal dysfunction, type 2 diabetes, cognitive impairment, depression, non-alcoholic fatty liver disease, cancer, and osteoarthritis (Leung et al., 2014). These diseases are costly to treat, and they lead to an increased likelihood of mortality. The authors highlighted that in 2003, obesity accounted for $7 \%$ of all deaths in Australia. Ellis and Savage (2008) also noted that a U.S. study indicated that disability has a positive correlation with obesity. These impacts are strong evidence for making governments see the seriousness of this health issue.

\subsubsection{Feasibility}

This stage concerns discussions regarding the policy implementation process. These discussions include four areas: the availability of technology, resources, infrastructure, and skilled workers.

\subsubsection{Availability of Technology}

Environmental and genetic factors are risk factors for obesity (Clément, 2005). Rey-López, Vicente-Rodríguez, Biosca, and Moreno (2008) stated that environmental factors are responsible for the role of energy intake and consumption in the body. These authors showed that environmental factors influence behavioural changes. Yoo and Kim (2012) also highlighted that media, such as television (TV), newspapers, and the internet, are significant influences that educate and encourage communities to change their behaviours positively, especially regarding this health issue. Medication for weight loss and bariatric surgery are both available in Australia (Leung et al., 2014). Bariatric surgery is a new technical surgical technique for treating obesity, and it has the best long-term result (Maggard et al., 2005).

\subsubsection{Resources}

Many data resources pertain to obesity in Australia; these include research studies and government documents. Research studies have covered all sides of this issue, including prevalence, treatment, and prevention. Obesity research centres, such as the one at Monash University (Monash Center for Obesity Research and Education, 2008), are also available. Government documents cover the cost, prevalence, and mortality of obesity (Australian Bureau of statistics, 2016b; Australian Institute of Health and Welfare, 2016b). Unhealthy food, tobacco, and alcohol are risk factors for obesity (Friel, 2009); Gortmaker et al. (2011) suggested that taxes should be placed on these risk factors.

\subsubsection{Infrastructure}

A country's infrastructure supports its activities and implementation of its policies. Australia is the sixth-largest country in the world in land mass (Department of Foreign Affairs and Trade, 2008). It has a significantly developed environment, a highly educated population, and more than 50 national parks. Moreover, the percentage of robbery victims decreased by 16\% during 2013-2014 (ABS, 2015b). Foster and Giles-Corti (2008) stated that physical activity has a positive association with the safety of neighbourhoods. Therefore, the Australian environment supports physical activity through its safe neighbourhoods and numerous parks. As pointed out by Aichberger et al. (2010), physical activity reduces the risk of developing obesity. In addition, Prichard and Tiggemann (2008) also stated that many gymnasiums and fitness centres in Australia are equipped 
with modern sports equipment, which helps to reduce weight faster and under safe conditions. Sixty percent of the Australian population, aged 14 and above, attended fitness clubs or gyms at least once per year, in 2013 and 2014 (ABS, 2015a). There were 1359 public and private hospitals in Australia in 2013 and 2014 (AIHW, 2016a). Ellis and Savage (2008) highlighted that private health insurance covers $100 \%$ of the population with a high level of health care. These hospitals provide screening, care, and low-cost treatment for serious cases of obesity. The Australian Bureau of statistics (2016a) stated that agricultural lands make up approximately 53\% of Australia, thereby indicating that numerous healthy foods are available locally. Thus, the infrastructure of Australia can support a new obesity policy if one is developed.

\subsubsection{Skilled Workers}

In 2013 and 2014, there were 610,148 health practitioners, such as dietitians, in Australia (AIHW, 2016c). The Dietitians Association of Australia provides professional standards for the education of dietitians (Cant \& Aroni, 2008). Food suppliers provide healthy, high-quality food both online and through supermarkets. Morland, Diez Roux, and Wing (2006) maintained that a a low prevalence of obesity has a positive association with the prevalence of supermarkets and higher in areas with a small number of stores or fast food restaurants. Therefore, skilled workers can reduce the pervasiveness of obesity through education and by providing healthy food.

\subsubsection{Public and Government Support in Relation to Policy Issues}

Public support assists the government in handling this issue more easily. Public support can be through schools, the community, and mass media.

First, all Australian schools provide programmes for physical activities and prevent students from consuming unhealthy foods (Bell \& Swinburn, 2004). These programmes encourage students to change unhealthy behaviours. Brien (2014) mentioned that the Stephanie Alexander Kitchen Garden Program has been conducted in primary schools to educate students about healthy food.

Second, communities can change unhealthy behaviours through activity groups and programmes such as Just Walk It (Chau, 2007). The author pointed out that the Just Walk It programmes include more than 300 groups throughout Australia. The same paper showed that government and non-government sectors have provided numerous sports programmes throughout Australia. Nichols et al. (2013) stated that there are 78 projects in Australia that deal with preventing obesity by encouraging the community to engage in physical activities and eat healthy food. In addition, there are many associations, such as the Australian Medical Association (AMA), that have made obesity one of their priorities (Australian Medical Association, 2013).

Third, the mass media views obesity as a societal health issue that needs solutions (C. M. Bonfiglioli, Smith, King, Chapman, \& Holding, 2007). The authors detail many individual TV programmes that both analyse and suggest solutions for the obesity issue in Australia. Public support can control risk factors for obesity at various levels in the schools, community, and mass media.

The obesity issue can be prioritized in agenda setting, as shown by the logic of the Hall model. Therefore, there are clear possible solutions, and the obesity issue is a public matter.

\subsection{Kingdon Model}

The Kingdon model concentrates on the role of actors who can influence government agenda setting. These actors could either be within or outside the government. However, action can only be taken when the problem stream, the policy stream, and the political stream come together.

\subsubsection{The Problem Stream}

Obesity is a serious health issue facing Australian society. The prevalence of overweight and obesity has been increasing for years. The Australian Institute of Health and Welfare [AIHW] (2016c) highlighted that the prevalence of overweight and obesity increased from $57 \%$ of the Australian population in 1995 , to $61 \%$ in $2007-$ 2008 , and $63 \%$ in 2011-2012. Moreover, at a cost of approximately $\$ 56.6$ billion in 2005, obesity has a substantial economic impact on Australia (Colagiuri et al., 2010). Robertson (2008) pointed out that Queensland's Premier established an obesity task group, now Eat Well Be Active, in 2006. The authors stated that the government viewed the issue in Queensland as serious in 2006. Consequently, the overweight and obesity rate has been reduced by $7 \%$ in adults. Moreover, Bibby (2014) highlighted that a 10-year-old boy died from obesity. Being obese had caused sleep apnoea and cardiac arrest for the boy, and his parents were careless about the doctor's advice. This issue was a public matter, and the mass media took it very seriously. Children pay with their lives for their parents' misunderstanding of the obesity risk. 


\subsubsection{The Policy Stream}

Obesity is a global issue that concerns all countries. Swinburn et al. (2011) stated that in 2004, the World Health Organisation (WHO) provided a global strategy for diet, physical activity, and health. The authors discussed a meeting held in New York by the United Nations (UN) member states to debate the issue of rising obesity in the world and its risk in the development of non-communicable diseases. The same paper also highlighted that there were approximately 502 million obese and 1.48 billion overweight adults throughout the world. The Men's Health Forum wrote about the obesity of men in England and Wales, which helped to implement obesity policy and actions in 2005 (Monaghan, 2005).

As is true with other developed countries, the obesity rate has been increasing rapidly in Australia over the past years. MacKay (2011) showed that approximately two-thirds of Australian adults and a quarter of the children are obese. Obesity costs Australia about $\$ 58.6$ billion, as mentioned previously. In addition, the media has debated the increasing prevalence of obesity and the risk of obesity in developing many chronic diseases (C. Bonfiglioli, Holding, Chapman, King, \& Smith, 2007). As noted by the authors, many TV channels, newspapers, and journals view obesity as a highly political issue.

The solution to this issue is divided into two parts: prevention and medical intervention (Leung et al., 2014). First, the authors highlighted that prevention can be started early during pregnancy and that obese women can decrease their weight before deciding to get pregnant. Therefore, developing a school environment to support physical activity and healthy food is required to produce a healthy new generation (Sallis \& Glanz, 2009). The same paper pointed out that taxes should be put on fast food restaurants, unhealthy food stores, and unhealthy food industries. The Nursing Standard (2014), which discusses a sugar tax on unhealthy suppliers, supports this issue. In addition, the media promotes physical activity and healthy food as a means to create activity-friendly communities, as stated by the authors. Second, medical interventions can be divided into categories: weight loss programmes, weight loss medication, and bariatric surgery (Leung et al., 2014). Therefore, although most of the solutions are available in society, they need action and policies to organise them. In addition, they also show the priority of obesity as an issue for agenda setting.

\subsubsection{The Political Stream}

The Prime Minister of Australia, Mr. John Howard, promised to spend \$118 million to treat the childhood obesity issue in 2004 (Kirk, 2004). As mentioned previously, the media made the issue of a 10-year-old boy who died from obesity in 2014 a public matter. Even before that though, in 2002, the New South Wales government put a plan into action to decrease obesity (NSW Government, 2008). The author mentioned that the implementation of the plan was through physical activity programmes and encouraging healthy food habits. In brief, these points should be used to encourage the government to act on the obesity issue.

The Hall model claims that obesity is an issue to be addressed in agenda setting because the obesity issue and possible solutions are high with regard to legitimacy, feasibility, and public support. Consequently, the obesity issue should be put on the policy agenda as a high priority. According to Zapelini (2014), in the Kingdon model, the health issue can be addressed by policy makers only if all three independent streams intersect at a critical moment, called a policy window. This involves a combination of the problem being identified, a solution evolving, and the political arena giving priority to addressing the obesity issue in agenda setting. The author highlighted that this is a weakness of this model because this process may take a long time. Therefore, the Hall model focuses on the solution and policy of obesity, while the Kingdon model focuses on the actors of policy and process; both give the obesity issue priority when it comes to agenda setting.

\section{Role of Different Groups in the Obesity Agenda}

There are different groups that support addressing the obesity problem and encourage the government to view this issue as a high priority in agenda setting. These groups have different levels of power and influence on the issue. In this paper, these groups are divided into four groups according to their level of power and influence. First, there are groups with low influence and low power to change the health of their community, such as individual Australians (Garran, 2009). Individuals can understand the dangers of obesity through mass media. The second group has high influence and low power; it includes media, researchers, social marketing campaigns, and health experts. Olds, Tomkinson, Ferrar, and Maher (2010) stated that researchers, media, and health experts are showing the rapidly increasing rate of obesity in Australia, which leads to making this issue a public matter and attracting the government's attention to it. Social marketing campaigns encourage communities to change their behaviour and understand the dangers of obesity, which causes the issue to be seen as a public matter (Bellows, Anderson, Gould, \& Auld, 2008; Morley, Wakefield, Dunlop, \& Hill, 2009). The third group has a 
high level of power and low influence, as in the private sector. Garran (2009); (Gortmaker et al., 2011) stated that private sectors can support the issue through resources and funding, which is part of the solution. The fourth group has both high influence and high power, as does the WHO, the UN, and associations. Branca, Nikogosian, and Lobstein (2007) showed that the WHO stated that obesity is a dangerous issue in developed countries and that Australia is one of them. Swinburn et al. (2011) also highlighted that the UN identified obesity in New York as a serious global issue. Therefore, governments should regard acting on this issue as a serious matter. The authors pointed out that associations have the influence and power to deal with governments regarding the obesity agenda. Indeed, many associations support the obesity issue in Australia, including the AMA and the Public Health Association. Nonetheless, the need for a combination of all groups to provide the issue with high priority and prioritize it in agenda setting is clear.

\section{Role of Government in obesity Agenda Setting}

The government always looks after the rights of the people. The government studies the priority of issues to put on the agenda (Althaus, 2013). Then, the issues with the highest priority are placed on the agenda. After that, the government has the ability to make its own policy on the issues, such as the limitation of responsibility. The same paper stated that other issues in the agenda were sorted by priority and then transferred to higher-level policy makers.

\section{Current Obesity Policy}

Approximately two-thirds of adults were overweight and obese in Australia during 2011 and 2012 (AIHW, 2016b). The same paper showed that a quarter of children were overweight and obese. The ABS, Australian Bureau of Statistics [ABS] (2011) mentioned that the death rate was 0.9 per 100,000 people in 2009. Obesity cost Australia approximately $\$ 56.6$ billion in 2005 (Colagiuri et al., 2010). Therefore, the current obesity policy is not effective enough, so updating or revising it is needed.

\subsection{Limitations}

This paper used only two models, the Hall and Kingdon models, for addressing the priority of the obesity issue when it comes to agenda setting.

\section{Conclusion}

The prevalence of obesity is increasing rapidly in Australia. This issue can be a priority for agenda setting, as shown by the Hall and Kingdon models. According to the Hall model, obesity, and its possible solutions are high in terms of legitimacy, feasibility, and public support. In comparison, the three independent streams of the Kingdon model should come at the critical moment to ensure it is addressed in agenda setting. In addition, four groups with different levels of power and influence play different roles in policy agenda setting. The government has high power and influence to choose the issues with high priority for agenda setting. Moreover, the current policy may need to be reviewed or updated because of the high prevalence of obesity and the rate of death. More research may be needed regarding the effectiveness of the current policy.

\section{Competing Interests Statement}

The authors declare that there are no competing or potential conflicts of interest.

\section{References}

Aichberger, M. C., Busch, M. A., Reischies, F. M., Ströhle, A., Heinz, A., \& Rapp, M. A. (2010). Effect of Physical Inactivity on Cognitive Performance after 2.5 Years of Follow-Up: Longitudinal Results from the Survey of Health, Ageing, and Retirement (SHARE). GeroPsych: The Journal of Gerontopsychology and Geriatric Psychiatry, 23(1), 7-15. http://dx.doi.org/10.1024/1662-9647/a000003

Althaus, C. (2013). Institutions of public policy. Retrieved from http://edocs.library.curtin.edu.au/eres_display.cgi?url=DC60269522.pdf\&copyright=1

Australian Bureau of Statistics. (2015a). Participation in Sport and Physical Recreation, Australia (No.4177.0), 2013-14 Retrieved from http://www.abs.gov.au/ausstats/abs@.nsf/mf/4177.0

Australian Bureau of Statistics. (2015b). Recorded Crime - Victims, Australia (No.45100DO002), 2013. Retrieved from http://www.abs.gov.au/AUSSTATS/abs@.nsf/DetailsPage/4510.02013?OpenDocument

Australian Bureau of statistics. (2016a). Agricultural Commodities, Australia (No. 7121.0), 2014-15. Retrieved from http://www.abs.gov.au/ausstats/abs@.nsf/mf/7121.0
Australian
Bureau
of statistics.
(2016b).
obesity
data.
Retrieved
from 
http://search.abs.gov.au/s/search.html?query=obesity + data\&collection=abs\&form=simple \&profile=_default preview

Australian Bureau of Statistics [ABS]. (2011). Causes of Death, Australia (No.3303.00, 2009). Retrieved from http://www.abs.gov.au/ausstats/abs@.nsf/0/5D2583A806EB4B60CA25788400127C98?opendocument

Australian Institute of Health and Welfare. (2016a). Hospital. Retrieved from http://www.aihw.gov.au/hospitals/

Australian Institute of Health and Welfare. (2016b). search: Overweight and obesity data. Retrieved from http://www.aihw.gov.au/search/?q=obesity+data

Australian Institute of Health and Welfare. (2016c). Workforce. Retrieved from http://www.aihw.gov.au/workforce/

Australian Institute of Health and Welfare [AIHW]. (2016a). Body Weight. Retrieved from http://www.aihw.gov.au/body-weight/

Australian Institute of Health and Welfare [AIHW]. (2016b). Overweight and obesity. Retrieved from http://www.aihw.gov.au/overweight-and-obesity/

Australian Institute of Health and Welfare [AIHW]. (2016c). Who is overweight? Retrieved from http://www.aihw.gov.au/who-is-overweight/\#children

Australian Medical Association. (2013). Obesity - an AMA Priority. Retrieved from https://ama.com.au/ausmed/obesity-ama-priority

Béland, D. (2005). Ideas and Social Policy: An Institutionalist Perspective. Social Policy \& Administration, 39(1), 1-18. http://dx.doi.org/10.1111/j.1467-9515.2005.00421.x

Bell, A. C., \& Swinburn, B. A. (2004). What are the key food groups to target for preventing obesity and improving nutrition in schools? European Journal of Clinical Nutrition, 58(2), 258. http://dx.doi.org/10.1038/sj.ejcn.1601775

Bellows, L., Anderson, J., Gould, S. M., \& Auld, G. (2008). Formative research and strategic development of a physical activity component to a social marketing campaign for obesity prevention in preschoolers. Journal of Community Health, 33(3), 169-178. https://doi.org/10.1007/s10900-007-9079-z

Bibby, P. (2014). Morbidly obese child died following parental neglect and systemic failures, coroner finds. Retrieved from http://www.smh.com.au/nsw/morbidly-obese-child-died-following-parental-neglect-and-systemic-failures-c oroner-finds-20140926-10mqxu.html\#ixzz3Eb9J6sUF

Bonfiglioli, C., Holding, S., Chapman, S., King, L., \& Smith, B. (2007). Obesity in the media: political hot potato or human interest story? Australian Journalism Review, 29(1), 53. https://doi.org/10.5694/j.1326-5377.2007.tb01354.x

Bonfiglioli, C. M., Smith, B. J., King, L. A., Chapman, S. F., \& Holding, S. J. (2007). Choice and voice: obesity debates in television news. Medical Journal of Australia, 187(8), 442.

Branca, F., Nikogosian, H., \& Lobstein, T. (2007). The challenge of obesity in the WHO European Region and the strategies for response: summary: World Health Organization.

Brien, J. (2014). Childhood nutrition and the Stephanie Alexander kitchen garden program. Every Child, 20(3), 34.

Cant, R., \& Aroni, R. (2008). From competent to proficient nutrition education and counselling competency dilemmas experienced by Australian clinical dietitians in education of individuals. Nutrition \& Dietetics, 65(1), 84-89. https://doi.org/10.1111/j.1747-0080.2007.00190.x

Chau, J. (2007). Physical activity and building stronger communities: a report prepared for the premier's council for active living. Retrieved from http://www.pcal.nsw.gov.au/_data/assets/file/0004/27679/Physical_ Activity_Building_Stronger_Communities.pdf

Clément, K. (2005). Genetics of human obesity. Proceedings of the Nutrition Society, 64(2), 133-142. http://dx.doi.org/10.1079/PNS2005416

Colagiuri, S., Lee, C., Colagiuri, R., Magliano, D., Shaw, J. E., Zimmet, P. Z., \& Caterson, I. D. (2010). The cost of overweight and obesity in Australia. Med $J$ Aust, 192(5), 260-264. https://doi.org/10.5694/j.1326-5377.2010.tb03503.x

Dearing, J. W., \& Rogers, E. M. (1996). Agenda-Setting. Thousand Oaks: Thousand Oaks: SAGE Publications. 
Department of Foreign Affairs and Trade. (2008). About Australia. Retrieved from www.dfat.gov.au

Ellis, R., \& Savage, E. (2008). Run for cover now or later? The impact of premiums, threats and deadlines on private health insurance in Australia. International Journal of Health Care Finance and Economics, 8(4), 257-277. http://dx.doi.org/10.1007/s10754-008-9040-4

Foster, S., \& Giles-Corti, B. (2008). The built environment, neighborhood crime and constrained physical activity: An exploration of inconsistent findings. Preventive Medicine, 47(3), $241-251$. http://dx.doi.org/10.1016/j.ypmed.2008.03.017

Friel, S. (2009). Health equity in Australia: A policy framework based on action on the social determinants of obesity, alcohol and tobacco. Australian National Preventative Health Taskforce.

Garran, R. (2009). Australia: The Healthiest Country by 2020.

Gortmaker, S. L., Swinburn, B. A., Levy, D., Carter, R., Mabry, P. L., Finegood, D. T., . . Moodie, M. L. (2011). Changing the future of obesity: science, policy, and action. The Lancet, 378(9793), 838-847. https://doi.org/10.1016/S0140-6736(11)60815-5

Kirk, A. (2004). PM promises to spend on childhood obesity solutions. Retrieved from http:/www.abc.net.au/worldtoday/content/2004/s1142782.htm

Leung, J., Funder, J., \& Clark, S. (2014). Obesity: A National Epidemic and its Impact on Australia. Retrieved from www.obesityaustralia.org/_literature.../No_Time_To_Weight_Report

MacKay, S. (2011). Legislative solutions to unhealthy eating and obesity in Australia. Public health, 125(12), 896-904. https://doi.org/10.1016/j.puhe.2011.06.004

Maggard, M. A., Shugarman, L. R., Suttorp, M., Maglione, M., Sugerman, H. J., Livingston, E. H., .. . Hilton, L. (2005). Meta-analysis: surgical treatment of obesity. Annals of internal medicine, 142(7), 547-559. https://doi.org/10.7326/0003-4819-142-7-200504050-00013

Monaghan, L. F. (2005). Discussion piece: A critical take on the obesity debate. Social Theory \& Health, 3(4), 302-314. https://doi.org/10.1057/palgrave.sth.8700058

Monash Center for Obesity Research and Education. (2008). House of Representstives Standing Committee on Health and Ageing Inquiry into Obesity. Retrieved from www.aphref.aph.gov.au-house-committee-has-.-obesity-subs-sub046.pdf

Morland, K., Diez Roux, A. V., \& Wing, S. (2006). Supermarkets, Other Food Stores, and Obesity: The Atherosclerosis Risk in Communities Study. American Journal of Preventive Medicine, 30(4), 333-339. http://dx.doi.org/10.1016/j.amepre.2005.11.003

Morley, B., Wakefield, M., Dunlop, S., \& Hill, D. (2009). Impact of a mass media campaign linking abdominal obesity and cancer: a natural exposure evaluation. Health education research, 24(6), 1069-1079. https://doi.org/10.1093/her/cyp034

National Health and Medical Research Council. (2016). Obesity and Overweight. Retrieved from https://www.nhmrc.gov.au/health-topics/obesity-and-overweight

Nichols, M. S., Reynolds, R. C., Waters, E., Gill, T., King, L., Swinburn, B. A., \& Allender, S. (2013). Community-based efforts to prevent obesity: Australia-wide survey of projects. Health Promotion Journal of Australia, 24(2), 111-117. https://doi.org/10.1071/HE13001

NSW Government. (2008). Inquriy into Obersity in Australia. Retrieved from https://www.parliament.nsw.gov.au/prod/parlment/.../ObesityGG2.pd

Nursing Standard. (2014). Sugar tax would help cut obesity and preventable conditions, government told. Nursing Standard, 28(42), 0-0. http://dx.doi.org/10.7748/ns.28.42.0.2842988

Olds, T. S., Tomkinson, G., Ferrar, K., \& Maher, C. (2010). Trends in the prevalence of childhood overweight and obesity in Australia between 1985 and 2008. International journal of obesity, 34(1), 57-66. https://doi.org/10.1038/ijo.2009.211

Prichard, I., \& Tiggemann, M. (2008). Relations among exercise type, self-objectification, and body image in the fitness centre environment: The role of reasons for exercise. Psychology of sport and exercise, 9(6), 855-866. https://doi.org/10.1016/j.psychsport.2007.10.005

Rey-López, J. P., Vicente-Rodríguez, G., Biosca, M., \& Moreno, L. A. (2008). Sedentary behaviour and obesity 
development in children and adolescents. Nutrition, metabolism, and cardiovascular diseases : NMCD, 18(3), 242-251. http://dx.doi.org/10.1016/j.numecd.2007.07.008

Robertson, S. (2008). inquiry into Obesity. Retrieved from www.aphref.aph.gov.au-house-committee-haa-.-obesity-subs-sub056.pdf

Sallis, J. F., \& Glanz, K. (2009). Physical activity and food environments: solutions to the obesity epidemic. Milbank Quarterly, 87(1), 123-154. https://doi.org/10.1111/j.1468-0009.2009.00550.x

Shah, D. V., McLeod, D. M., Gotlieb, M. R., \& Lee, N.-J. (2009). Framing and agenda setting: na.

Swinburn, B. A., Sacks, G., Hall, K. D., McPherson, K., Finegood, D. T., Moodie, M. L., \& Gortmaker, S. L. (2011). The global obesity pandemic: shaped by global drivers and local environments. The Lancet, 378(9793), 804-814. https://doi.org/10.1016/S0140-6736(11)60813-1

Thorburn, A. W. (2005). Prevalence of obesity in Australia (Vol. 6, pp. 187-189). Oxford, UK. https://doi.org/10.1111/j.1467-789X.2005.00187.x

Yoo, J. H., \& Kim, J. (2012). Obesity in the New Media: A Content Analysis of Obesity Videos on YouTube. Health Communication, 27(1), 86-97. http://dx.doi.org/10.1080/10410236.2011.569003

Zapelini, M. (2014). Montagem de Agenda no Comitê Itajaí: Uma Aplicação do Modelo de Kingdon/Agenda Setting at the Comitê Itajaí: An Application of the Kingdon Model. Revista de Administração Contemporânea, 18(6), 795-VII. https://doi.org/10.1590/1982-7849rac20141214

\section{Copyrights}

Copyright for this article is retained by the author(s), with first publication rights granted to the journal.

This is an open-access article distributed under the terms and conditions of the Creative Commons Attribution license (http://creativecommons.org/licenses/by/4.0/). 